\title{
Resilience and Reproductive Health Diagnosis in Mexican Indigenous Women
}

\author{
Patricia Elizabeth Cossio Torres ${ }^{*}$, Aldanely Padrón-Salas ${ }^{\dagger}$, \\ Xiomara Sarahí Sanjuan-Meza ${ }^{\ddagger}$, Amado Nieto-Caraveo ${ }^{\S}$ and \\ Sara de Jesús Martínez-Granada**
}

\section{Abstract}

Mental Health is a determinant of reproductive mortality and morbidity especially in the developing regions of the world with reproductive health problems. The right to sexual and reproductive health has been enunciated by the United Nations as a goal to be achieved by 2030 . However, indigenous women are the most vulnerable population because of the conditions that surround them. A cross-sectional quantitative study was done in the indigenous communities of Mexico to know the resilience and reproductive health diagnosis. A Mexican Resilience Scale, gynaeco-obstetrical clinical history and a reproductive health survey were applied. A total of 180 women participated from which $34.6 \%$ and $61.4 \%$ of the women used a form of birth control method in their first and last sexual intercourse, respectively. There were statistically significant differences between the three attitudes among reproductive health and the highest levels of resilience $(\mathrm{p}<0.05)$. Resilience was seen to have a positive influence on the attitude of indigenous women, reducing the vulnerability among reproductive health.

Keywords: Reproductive Health of Women, Diagnosis, Indigenous

Public Health Department, School of Medicine(SM), Autonomous University of San Luis Poto(AUSLP), Mexico; patricia.cossio@uaslp.mx

† (SM), (AUSLP), Mexico; aldanely.padron@gmail.com

‡(SM),(AUSLP), Mexico; alohaxio@gmail.com

§ (SM), (AUSLP), Mexico; amadonieto@gmail.com

** (SM), (AUSLP), Mexico; sarahmg.cas@gmail.com 
ORCiDs: 0000-0002-7626-8949

\section{Introduction}

Mental health problems may develop as a consequence of reproductive health problems or events. However, there is minimal consideration of mental health as a determinant of reproductive mortality and morbidity especially in the developing regions of the world (WHO, 2009). Women are at a higher risk of mental health problems because they carry an unequal unpaid workload of their household tasks, care for children or other dependent relations.

According to the World Health Organization (WHO, 2009), the study of women's bodies and reproductive events have been separated from the study of their minds, including their attitudes and responses to these events.

Reproductive health is fundamental for people, couples and families as well as for the social and economic development of communities and nations (WHO, 2003). Its benefits range from poverty reduction, maternal and infant mortality to an improvement in the quality of life, which is translated into better education and employment opportunities as well as an equal inclusion of women into society (Allen-Leigh et al., 2013).

Several studies have demonstrated the influence of socioeconomic level, the place of residence and membership of a particular social group, indigenous or not, on fertility and reproductive health (INM n.d.; Hernández-López, Hernández-Vázquez and Sánchez-Castillo, 2013).

Voluntary access to safer methods of family planning is a human right, and it is the key to reaching gender equality and the strengthening of women (ONU, 2017a). While there have been advances regarding gender equality, women and girls, specially indigenous ones, are still suffering from discrimination and violence everywhere around the world (ONU, 2017b).

Mexico ranks eighth worldwide and first in Latin America among the countries with the most significant number of indigenous peoples (UNFPA, 2010) where the groups with the highest socioeconomic levels have fewer children, while the most 
vulnerable people such as the poor and indigenous have greater difficulty for controlling their fertility and therefore have lower reproductive health (UNFPA, 2010).

Reproductive health addresses the mechanisms of procreation as well as the functioning of the reproductive system in all life stages. This conception assumes that women can choose safe, effective, affordable and acceptable fertility control methods, have a followup during pregnancy and pleasurable sexuality (OMS, 2017a). However, indigenous women are some of the vulnerable groups with regards to their sexual and reproductive health (HernándezLópez, 2013). For indigenous women, territorial exclusion, lack of education, health injustice and social rights, difficulty in accessing information and adequate services makes it almost impossible to have a healthy reproductive status (Chávez-Galindo, 2003; Karver, 2016; Jiménez, 2017).

Nonetheless, some individuals are able to withstand stress, deal with pressure under conflicting, violent or vulnerable situations. Further, they design strategies that help them overcome adversities and even emerge stronger. These social and personal processes are known as resilience (Herman, 2011).

The development of resilience consists of promoting elements such as social support, emotional regulation abilities, self-consciousness, self-concept and capacity of visualizing the future, which are crucial elements for the full enjoyment and development of a good sexual and reproductive health (Pinto, 2014).

Resilience is the individual, family, community or organizational capacity to develop processes to cope, adapt and thrive in adverse situations. This concept was adapted to social sciences to enable people, despite being living in risk situations, to face the circumstances and come out stronger and from them. (UNLA, 2004; (Tomás, 2012).

This study was conducted to establish the status of resilience and reproductive health in the sample. Besides, it was carried out to know if there are differences between resilience and reproductive health status of indigenous women. 


\section{Methodology}

An initial meeting was done with the local authorities, as well as their family members and/or spouses, to whom the procedure was explained. Then, a community forum was conducted with the women of reproductive age of the communities to invite them to participate in the project.

All indigenous women of reproductive age from 12 different localities were included. Interested women gave their written consent after being informed of the risks and benefits of their participation. Also, confidentiality and freedom to abandon the project at all times were maintained.

Three written instruments were applied: the first was a clinical history emphasizing the gynecological history, purposely designed for this project. The second instrument was the adapted version of Knowledge, Attitudes and Practices in sexual and reproductive health Questionnaire, taken from the version of Vargas-Ruíz (2005) in Colombia, which was validated in this population. This questionnaire contained four subscales in its original version (Sexual Health Scale, Reproductive Health Scale, HIV/AIDS/STD Scale and the Condom Use Scale), each with three dimensions (Knowledge, Attitudes and Practices) and questions with Likert or dichotomous answers. Subscales of Reproductive Health (59 items) and Use of condom (54 items), with their three corresponding dimensions were taken into account for the present work.

The third questionnaire was the Mexican Resilience Scale validated in indigenous Mexican women (Sanjuan, 2018). The total resilience score has a minimum of 4 and a maximum of 20 index score. The instrument consists of 43 items and highlights features of resilient personalities in different levels (individual, family and society).

For statistical analysis, the SPSS data package version 19 was used. Descriptive statistics of the variables was carried out, frequency measures and proportions for qualitative variables were done as well as central tendency and dispersion measures for the quantitative variables were calculated. For the bivariate analysis, the Kruskal-Wallis test and Spearman correlation were used. 
The present work was approved by a Research Ethics Committee belonging to a public educational institution in Mexico.

\section{Results}

The population was made up of 180 indigenous women, $83.3 \%$ $(n=108)$ of which reported their age, which varied between 9 and 48 years with a mean of 33.15 years $(\mathrm{SD} \pm 9.47)$, with the most frequent population being the one between 26 and 45 years of age (60\%).

The $91 \%$ of participants had already begun their sex life, which had started on average at 18.1 years of age $(S D+3.7$ years) and $60.8 \%$ of the women started theirs between 15 and 18 years of age (only $41.1 \%$ of participants answered this data). Furthermore, it was found that $95.7 \%$ of women had had between one or two sexual couples $(76.3 \%$ and $19.4 \%$ respectively). Sixty five percent of them did not use a contraceptive method in their first sexual intercourse, decreasing the proportion of women to $38.6 \%$ who in their last sexual intercourse did not use any method. Table 1

The previous coincided, when participants were asked if they agreed to have sexual intercourse without using a contraceptive method $(34.4 \%)$, and $24.2 \%$ mentioned they neither agreed nor disagreed. From the women who used contraceptive methods, $13.4 \%$ used the female condom, and $28.3 \%$ reported to have used the male condom.

Table 1: The Use of Contraceptives in Indigenous Women of Mexico.

\begin{tabular}{|c|c|c|c|c|}
\hline \multirow{2}{*}{$\begin{array}{l}\text { Contraceptive } \\
\text { Method Used }\end{array}$} & \multicolumn{2}{|c|}{ First sexual intercourse } & \multicolumn{2}{|c|}{ Last sexual intercourse } \\
\hline & Frequency & Percentage & Frequency & Percentage \\
\hline \multicolumn{5}{|l|}{ Use of contraceptives } \\
\hline None & 104 & 65.4 & 61 & 38.6 \\
\hline Condom & 52 & 32.7 & 30 & 19.0 \\
\hline Pills & 2 & 1.3 & 2 & 1.2 \\
\hline Injections & 1 & 0.6 & 6 & 3.8 \\
\hline Implant & - & - & 14 & 8.9 \\
\hline Intrauterine Device & - & - & 26 & 16.5 \\
\hline Tubal Ligation & - & - & 14 & 8.9 \\
\hline Withdrawal & - & - & 4 & 2.5 \\
\hline Patches & - & - & 1 & 0.6 \\
\hline
\end{tabular}




\begin{tabular}{lcc}
\hline Contraceptive Behavior & Frequency & Percentage \\
\hline $\begin{array}{l}\text { Has Sexual Intercourse without } \\
\text { contraceptive use }\end{array}$ & & \\
Agree & 54 & 34.4 \\
Neither agree nor disagree & 38 & 24.2 \\
Disagree & 65 & 41.4 \\
Has used the female condom & & \\
Agree & 21 & 13.4 \\
Neither agree nor disagree & 5 & 3.2 \\
Disagree & 131 & 83.4 \\
Agree & & \\
Neither agree nor disagree & 45 & 28.3 \\
Disagree & 38 & 23.9 \\
Condom & 76 & 47.8 \\
\hline
\end{tabular}

Concerning pregnancy, $89.4 \%$ reported being pregnant sometimes, and $88.6 \%$ had more than five medical consults during their prenatal control. Thirty seven percent reported having a disease during their last pregnancy, the most frequent being urinary tract infection (64.2\%) and anaemia (26.9\%).

From the women that were pregnant, $17.1 \%$ had some form of complication during delivery in their last gestation, the wrong position of the baby was the most frequent factor (34.5\%). Twelve percent of women were treated in their homes during their last delivery. The remaining $88.0 \%$ were treated at some health institution, $77.2 \%$ of which were given a contraceptive method, the most frequent being the intrauterine device $(64 \%)$ followed by tubal ligation in $21.3 \%$ of women.

It is worth mentioning that although the frequency of attention by physicians is higher by $86.7 \%$, the care by midwives is present in the study location by $8.2 \%$. Regarding breastfeeding, $59.3 \%$ of the population was found to have breastfed their last baby for over a year (see table 2). 
Table 2: Gynaeco-obstetrical Background of the Last Pregnancy of Indigenous Women of Mexico

\begin{tabular}{lll}
\hline Condition & Frequency & Percentage \\
\hline
\end{tabular}

Information on Family planning is provided

Always or almost always $\quad 141$

79.7

Sometimes

Never or rarely

Prenatal control

Less than 5 consults

5 or more consults

Conditions during their last pregnancy

Urinary tract infection

Hypertension

Abortion threat

Preeclampsia

Sexually transmitted disease

HIV AIDS infection

Vaginal bleeding

Complications during delivery

Incorrect positioning of the baby

Abundant vaginal

bleeding/Hemorrhage

Preeclampsia/Eclampsia

Obstructed labor

Premature delivery

Complications due to a disease that the person already had

Placenta retention

Preeclampsia+abundant vaginal bleeding

Eclampsia

Hyperglycemia or diabetes

Another disease

Person who assisted the last delivery

General Physician

Midwife

Husband

Nurse

Gynecologist 
Where you given a contraceptive method before leaving the hospital or the place where you were treated?

$\begin{array}{lcc}\text { Yes } & 122 & 77.2 \\ \text { No } & 36 & 22.8\end{array}$

Which method where you given?

$\begin{array}{lcc}\text { Intrauterine Device } & 64 & 64.0 \\ \text { Tubal Ligation } & 26 & 21.3 \\ \text { Implant } & 11 & 9.0 \\ \text { Pills } & 4 & 3.3 \\ \text { Injection } & 3 & 2.5 \\ \text { Condom } & 1 & 0.8 \\ \text { Did not specify } & 13 & 10.6 \\ \text { Did not breastfeed } & & \\ \text { Less than 6 months } & 6 & 3.8 \\ \text { 6 months } & 16 & 10.2 \\ 7 \text { months to 1 year } & 13 & 8.3 \\ \text { From one year to less than } 2 & 29 & 18.5 \\ \text { years } & 48 & 30.6 \\ \text { Over 2 years } & 45 & 28.7\end{array}$

Breastfeeding period of the last child

About the behaviour and attitudes identified, it was found that $87.6 \%$ always or almost always would talk to their partner in case of having a sexually transmitted disease, which was consistent with the $66.4 \%$ who reported talking about sexually transmitted diseases (Table 3).

On the other hand, an existing faulty knowledge was found concerning the contraceptive methods that they know, 50.6\% considered applying Vaseline, hand cream or oil to achieve greater lubrication. Sixty percent believed that the condom can withstand high temperatures, $48.9 \%$ considered that it is good to inflate the condom before using it, $67.8 \%$ believed that the constant use of the condom can cause a person to suffer from some illness and $75 \%$ thought that birth control pills cause cancer. Thirty-nine percent considered that taking the penis out of the vagina before ejaculation is a contraceptive method, $34.5 \%$ believed that it is true that the birth control pill protects against HIV and other sexually transmitted diseases (data not shown).

Contrary to results shown in behaviour, regarding reproductive health knowledge, high prevalence's of an adequate knowledge 
were found, where $86.7 \%$ of the participants recognized that reproductive health implies having a satisfactory pregnancy, delivery and post-partum. $71.1 \%$ knew that men after turning 40 have to perform an annual prostate analysis, $93.8 \%$ knew that the condom is a method for the prevention of sexually transmitted diseases and $58.3 \%$ said they know how to use it (data not are shown).

Within the identified attitudes, it was found that $92.1 \%$ agreed that the health services to which they have access were safe, $55.4 \%$ said they accepted an abortion when the woman's health is at risk. Forty one percent related to the lack of confidence while asking their partners to wear a condom, apart from the fact that a condom should not be used if the partner is known (43.2\%), if one is in love $(40 \%)$ or if one is married $(21.6 \%)$. Table 3

A little over half of the participants identified that the responsibility over a pregnancy is not attributed only to the woman $(50.8 \%)$, which coincided with the answer in favour of the idea that the woman is not the only one who should take measures not to get pregnant $(46.8 \%)$ and men as well as women can suggest the use of the condom $(92.7 \%)$. However, $20 \%$ of them believe that the only purpose of having sex is to have children, and $18.8 \%$ consider that they must have all the children that are sent to them by God (data not shown).

Participants also reported that they have access to information on family planning $(79.5 \%)$, and contraceptive methods $(87 \%)$ and only $55 \%$ of them check their genitals all the time or most of the time looking for alterations. Table 3.

Table 3: Behaviors and attitudes regarding reproductive health and the use of the condom in indigenous women of Mexico.

\begin{tabular}{ccc}
\hline Behaviours and attitudes & Frequency & Percentag \\
\hline I would talk to my partner if I had a sexually transmitted & disease \\
Always or almost always & 155 & 87.6 \\
Sometimes & 14 & 7.9 \\
Never or rarely & 8 & 4.5 \\
I talk to my partner about sexually transmitted diseases & \\
Always or almost always & 81 & 66.4 \\
Sometimes & 22 & 18.0
\end{tabular}


Never or rarely

Security in the attention of health services

Agree

Neither agree nor disagree

Disagree

The right to interrupt a pregnancy when there is a health risk

$\begin{array}{lll}\text { Agree } & 98 & 55.4 \\ \text { Neither agree nor disagree } & 47 & 26.5 \\ \text { Disagree } & 32 & 18.1\end{array}$

The right to interrupt a pregnancy under any circumstance

$\begin{array}{lll}\text { Agree } & 45 & 25.6 \\ \text { Neither agree nor disagree } & 43 & 24.4 \\ \text { Disagree } & 88 & 50.0\end{array}$

Asking for the use of a condom is due to the lack of trust

$\begin{array}{lcc}\text { Agree } & 73 & 41.2 \\ \text { Neither agree nor disagree } & 44 & 24.9 \\ \text { Disagree } & 60 & 33.9\end{array}$

The use of the condom is not necessary if you know the person well

$\begin{array}{lll}\text { Agree } & 76 & 43.2 \\ \text { Neither agree nor disagree } & 42 & 23.9 \\ \text { Disagree } & 58 & 33.0\end{array}$

If there is love in between the use of the condom is unnecessary

$\begin{array}{lll}\text { Agree } & 70 & 40.0 \\ \text { Neither agree nor disagree } & 26 & 14.9 \\ \text { Disagree } & 79 & 45.1\end{array}$

Once married the use of the condom is unnecessary

$\begin{array}{lll}\text { Agree } & 38 & 21.6 \\ \text { Neither agree nor disagree } & 45 & 25.6 \\ \text { Disagree } & 93 & 52.8\end{array}$

Pregnancy is mainly a woman's responsibility

$\begin{array}{lcc}\text { Agree } & 83 & 46.9 \\ \text { Neither agree nor disagree } & 4 & 2.3 \\ \text { Disagree } & 90 & 50.8\end{array}$

It is the woman who should take measures to avoid pregnancy

$\begin{array}{lcc}\text { Agree } & 76 & 43.5 \\ \text { Neither agree nor disagree } & 17 & 9.7 \\ \text { Disagree } & 82 & 46.8\end{array}$

Men, as well as women, can suggest the use of the condom

Agree

Neither agree nor disagree 
Disagree

Has access to information on family planning

$\begin{array}{lrc}\text { Always or almost always } & 140 & 79.5 \\ \text { Sometimes } & 25 & 14.2 \\ \text { Never or rarely } & 11 & 6.3\end{array}$

Has access to places where contraceptive methods can be obtained

$\begin{array}{lcc}\text { Always or almost always } & 154 & 87.0 \\ \text { Sometimes } & 17 & 9.6 \\ \text { Never or rarely } & 6 & 3.4\end{array}$

The mean level of resilience was of 17.25 (SD \pm 2.14$)$. Finally, there were statistically significant differences between the three attitudes among reproductive health and the highest levels of resilience. Table 4.

Table 4: Mean rank differences among Total Resilience Scale and reproductive health - use of the condom in indigenous women of Mexico.

\begin{tabular}{|c|c|c|c|c|c|c|}
\hline $\begin{array}{c}\text { Behaviour / } \\
\text { Attitude }\end{array}$ & $\begin{array}{l}\text { Totall } \\
\text { y des } \\
\text { agree }\end{array}$ & $\begin{array}{c}\text { Des } \\
\text { agree }\end{array}$ & $\begin{array}{c}\text { Not } \\
\text { agree/not } \\
\text { disagree }\end{array}$ & Agree & $\begin{array}{c}\text { Totally } \\
\text { Agree }\end{array}$ & $\begin{array}{c}\mathrm{p}- \\
\text { value }\end{array}$ \\
\hline $\begin{array}{l}\text { Security in } \\
\text { the attention } \\
\text { of health } \\
\text { services. }\end{array}$ & 85.33 & 53.88 & 30.6 & 82.98 & 82.57 & 0.111 \\
\hline $\begin{array}{l}\text { The right to } \\
\text { interrupt a } \\
\text { pregnancy } \\
\text { when there is } \\
\text { a health risk. }\end{array}$ & 82.28 & 79.18 & 79.86 & 80.37 & 82.73 & 0.999 \\
\hline $\begin{array}{l}\text { The right to } \\
\text { interrupt a } \\
\text { pregnancy } \\
\text { under any } \\
\text { circumstance. }\end{array}$ & 67.54 & 80.49 & 67.49 & 95.23 & 115.8 & 0.008 \\
\hline $\begin{array}{l}\text { Asking for } \\
\text { the use of a } \\
\text { condom is } \\
\text { due to the } \\
\text { lack of trust. }\end{array}$ & 75.6 & 93.78 & 68.71 & 82.55 & 76 & 0.174 \\
\hline $\begin{array}{l}\text { The use of the } \\
\text { condom is } \\
\text { not necessary }\end{array}$ & 96.53 & 71.98 & 74.66 & 85.04 & 80.78 & 0.357 \\
\hline
\end{tabular}


if you know

the person

well.

If there is

$83.61 \quad 82.93 \quad 65.78$

$87.01 \quad 69.47$

0.328

love in

between the

use of the

condom is

unnecessary.

Once married

the use of the

condom is

unnecessary.

Pregnancy is

$\begin{array}{lll}83.28 & 87.05 & 45.17\end{array}$

$\begin{array}{lll}78.26 & 70.67 & 0.403\end{array}$

mainly a

woman's

responsibility

It is the

$85.71 \quad 84.13 \quad 42.03$

$\begin{array}{lll}83.11 & 79.63 & \mathbf{0 . 0 2 4}\end{array}$

woman who

should take

measures to

avoid

pregnancy.

Men, as well

as women,

can suggest

the use of the condom.

\begin{tabular}{llllccc}
\hline & Never & $\begin{array}{c}\text { Rare } \\
\text { ly }\end{array}$ & $\begin{array}{c}\text { Some } \\
\text { times }\end{array}$ & $\begin{array}{c}\text { Al } \\
\text { most } \\
\text { al } \\
\text { ways }\end{array}$ & $\begin{array}{c}\text { Al } \\
\text { ways }\end{array}$ & $\begin{array}{c}\text { p- } \\
\text { value }\end{array}$ \\
\hline $\begin{array}{l}\text { I would talk } \\
\text { to my partner }\end{array}$ & 24.86 & 15 & 81.11 & 80.85 & 84.04 & $\mathbf{0 . 0 1 2}$ \\
if I had a & & & & & & \\
$\begin{array}{l}\text { sexually } \\
\text { transmitted }\end{array}$ & & & & & & \\
$\begin{array}{l}\text { disease. } \\
\text { I talk to my } \\
\text { partner about } \\
\text { sexually }\end{array}$ & 59.15 & 55.14 & 56.16 & 44.84 & 61.01 & 0.364 \\
transmitted & & & & & & \\
diseases. & & & & & & \\
58 & & & & & \\
58 & & & & & &
\end{tabular}




$\begin{array}{lllllll}\begin{array}{l}\text { Has access to } \\ \text { information }\end{array} & 67.83 & 132.5 & 74.41 & 73.39 & 82.82 & 0.366 \\ \begin{array}{l}\text { on family } \\ \text { planning. }\end{array} & & & & & & \\ \begin{array}{l}\text { Has access to } \\ \text { places where }\end{array} & 64.75 & 74 & 69.5 & 80.05 & 82.82 & 0.797 \\ \begin{array}{l}\text { contraceptive } \\ \text { methods can } \\ \text { be obtained. }\end{array} & & & & & & \\ \end{array}$

${ }^{*} \mathrm{p}<0.05$ Kruskall-Wallis Test

\section{Discussion}

This study was conducted to establish the status of resilience and reproductive health in indigenous women, and the relationship between them. We found a lower prevalence to the lack of contraceptive method in their last sexual intercourse (38.6\%), in comparison with the national and state levels reported in Mexico and San Luis Potosí (55 and 57\% respectively) (Allen-Leigh et al.; INEGI, 2015). However, almost 25\% neither agree nor disagree to the use of contraceptives and condom use. The most contraceptive method used after delivery was the intrauterine device, however, this is a method not appropriate to install just right after the delivery since it is important for the uterus return to this normal size. The forty percent of the women offered to breastfeed until one-year-old of their last child, opposite to the recommendation of the WHO (until two years old, (INSP \& UNICEF, 2016).

We found that the highest levels of resilience were associated with three attitudes among reproductive health. In the attitude of "The right to interrupt a pregnancy under any circumstance" between the group of totally agree and totally disagree, this could be a reflection of the self-steem of women, a key element for the presence of resilience. Another attitude with significant differences among resilience levels was that women should take measures to avoid pregnancy, where the higher levels were in the group of totally disagree. Lastly, the highest levels of resilience were found in the group who would talk to their partners if they had a Sexual Transmitted Disease.

A high level of resilience has shown to have a positive influence on the attitude of the indigenous women. This relationship could reduce the situation of vulnerability to which they are exposed, 
because resilience is a protective factor, in this case, to the assertiveness in the decision making. These results are according to other studies among reproductive health (Hardee et al., 2018) or different positive outcomes including successful aging, lower depression, and longevity (Sarubin et al., 2015; Tomás et al., 2012; Hao et al., 2015).

The development of resilience consists of promoting elements such as social support, emotional regulation abilities, self-consciousness, self-concept and capacity of visualizing the future, which are key elements for full enjoyment and development of a good sexual and reproductive health (Pinto, 2014).

In regards to the beginning of sex life, it was found to be below what is reported by CONAPO (2009) where an average of 19 years of age was registered and was considered the same as what was published by the National Population Council in 2011 (CONAPO, 2011) who reported an average of 18 years of age. Notwithstanding the above, almost $61 \%$ of women began their sex life between 15 and 18 years of age, which is similar to what was observed in national polls (INEGI, 2016). This could turn out to be detrimental for this population, because, once they begin their sex life, their health needs change since they are exposed to infections and pregnancies (Gayet \& Gutierrez, 2014).

On the other hand, the use of a contraceptive method in the first sexual intercourse was far below the expected, since only $34.6 \%$ of the women used some method, contrary to what was reported by INEGI (2016), where it was observed that almost $50 \%$ of them had used some method and CONAPO, where it was $54.8 \%$ of women (CONAPO, 2014a). However, it was higher according to what was reported by CONAPO (2009), where utilization was reported to have varied between 11 and $20 \%$, according to the age of women, the older they are, the lower the use of the contraceptive method in the first intercourse. The condom was the most used contraceptive method reported in literature (CONAPO, 2014a). The efficacy of the condom as it is commonly used is $79 \%$, but it can be of up to $90 \%$ if it is used in a correct and sustained way (CDC, n.d.; OMS, 2017b).

Unlike the first sexual intercourse, where $65.4 \%$ of women did not use a contraceptive method, in the last sexual intercourse, the 
percentage decreases to $38.6 \%$, this last according to what was reported by Allen-Leigh and collaborators (2013), who obtained compatible figures with lower use of contraceptive methods with increasing age.

Within the services of attention to reproductive health, prenatal control represents a platform for the delivery of essential functions of care to the health of the pregnant woman and the future newborn, such as health promotion, screening and diagnosis, and disease prevention (OMS, 2016, OMS 2017b). In this case, it was found that $88.6 \%$ of women went to at least five prenatal consults, according to national and international recommendations (DOF, 2016; OMS, 2016).Regarding the delivery care performed by a doctor, the reported percentage $(88 \%)$ was below the national indicator, where it was reported that up to $94.8 \%$ were treated by doctors (CONAPO 2014b) and was below what was found in other indigenous populations (INM n.d.). The use of surgical contraceptive methods increases with age, and the intrauterine device was the most widely used after having their last obstetric event by what was reported in the literature (Allen-Leigh et al. 2013).

The practice of breastfeeding is one of the most critical determinants in the health of the first two years in the life of newborns. It has been reported that $93 \%$ of newborns initiated a process of breastfeeding; however, there were several reasons as to why they stopped doing it. The total duration of breastfeeding was of 9.2 months at a national level (CONAPO, 2014c), and the findings of this study corresponded to what was found in other indigenous populations where around $60 \%$ of women breastfed their children for over a year and a half (CONAPO, 2014a).

Adequate knowledge of contraceptives and their use is one initial condition for the potential access of the contraceptive practice. This study showed that 60 to $70 \%$ of participants have adequate knowledge about contraceptive methods and their use, however, there is a great area of opportunity available, since national surveys report that over $95 \%$ of the population are acquainted with at least one contraceptive method and know how to use it (CONAPO 2014d). 
This study has some weaknesses. The study focussed on female participants in vulnerable contexts, making findings difficult to generalise. Besides, the women who did not speak and write Spanish were excluded.

Lastly, gender differences existing in this population were observed in the present study. Thus, to initiate it, authority and family/spouse approval had to be obtained, which, despite being a result of their customs and traditions, violates their freedom of choice. The number of women who had difficulty providing certain information due to the shame that resulted from answering questions on tabooed issues stand out.

\section{Conclusion}

The mental health determinants have a crucial role in the reproductive health of the population. In this study, we evaluated the resilience as a variable that included strength and self confidence, social competence, family support, social support and structure. The levels of resilience of this population were high, and this variable was related to reproductive health attitude. Despite improvements in accessing information and health services, it was observed that indigenous women have poorer reproductive health, specially in attitudes and behaviour compared to national indicators. However, the presence of resilience should be noticed as a protective factor and be included in the design and implementation of health programmes.

\section{Funding}

This work was supported by the Consejo Nacional de Ciencia y Tecnología (CONACYT) under Grant number SALUD-2013-01202215

\section{References}

Allen-Leigh, B., Villalobos-Hernández, A., Hernández-Serrato, M. I., Suárez, L., Vara, E. D. L., de Castro, F., \& Schiavon-Ermani, R. (2013). Inicio de vida sexual, uso de anticonceptivos y planificación familiar en mujeres adolescentes y adultas en México. salud pública de méxico, 55, S235-S240. 
Centers for Disease Control and Prevention CDC. (n.a.). "Los condones y las ETS: Hoja informativa para el personal de salud pública". Retrieved from https://www.cdc.gov/condomeffectiveness/docs/condoms_and_std s_spanish.pdf

Chávez Galindo, A., Uribe Zúñiga, P. Y., \& Palma Cabrera, Y. (2003). “La salud reproductiva de la población indígena" In La salud reproductiva en México. Análisis de la Encuesta Nacional de Salud Reproductiva 2003(pp.175-190). Biblioteca digital de la UNAM. Retrieved from http:/ / biblioteca.clacso.edu.ar/Mexico/crim-unam/ 20100428102507/saludreproductiva.pdf

Consejo Nacional de Población CONAPO (2009). “Transiciones a la vida reproductiva y fecundidad" In Principales indicadores de salud reproductiva ENADID 2009. CONAPO. Retrieved from http:// www.conapo.gob.mx/ work/models/CONAPO/Resource/216/1/images/1TransicionesDe VidaBIS.pdf

Consejo Nacional de Población CONAPO (2011). Perfiles de salud reproductiva. Retrieved from http:// www.conapo.gob.mx/ en/ CONAPO/Republica_Mexicana_Perfiles_de_Salud_Reproductiva

Consejo Nacional de Población CONAPO (2014a.). "Mujeres en edad fértil sexualmente activas" In Indicadores de salud sexual y reproductiva. Resumen infográfico, San Luis Potosí. CONAPO. http:// www.conapo.gob.mx/ work/ models/ CONAPO/ Libros_Salud/ SL/ files/assets/basic-html/ page6.html

Consejo Nacional de Población CONAPO (2014b). “Tipo de atención al parto". In Libros de Salud. CONAPO. Retrieved from http:// www.conapo.gob.mx/

work/models/CONAPO/Libros_Salud/SL/files/assets/basichtml/page14.html

Consejo Nacional de Población CONAPO (2014c). "Lactancia". In Libros de Salud. CONAPO. Retrieved from http:// www.conapo.gob.mx/ work/ models/ CONAPO/Libros_Salud/SL/files/assets/basichtml/page14.html

Consejo Nacional de Población CONAPO (2014d). “Conocimientos de métodos anticonceptivos- San Luis Potosí". In Salud sexual y reproductiva. CONAPO. Retrieved from http:// www.conapo.gob.mx/ models/CONAPO/Libros_Salud/Infografias/Info_24_SL.pdf

Diario Oficial de la Federación DOF (2016). "NORMA Oficial Mexicana NOM-007-SSA2-2016, Para la atención de la mujer durante el embarazo, parto y puerperio, y de la persona recién nacida". Retrieved from http:/ / www.dof.gob.mx/ nota_ detalle. php? Codigo $=5432289 \&$ fecha $=$ 07/04/2016 
Gayet, C., \& Gutierrez, J. (2014). “Calendario de inicio sexual en México. Comparación entre encuestas nacionales y tendencias en el tiempo". Salud Pública de México, 56(6), 638-647.

Hao, S., Hong, W., Xu, H., Zhou, L., \& Xie, Z. (2015). Relationship between resilience, stress and burnout among civil servants in Beijing, China: Mediating and moderating effect analysis. Personality and Individual Differences, 83, 65-71.

Hardee, K., Patterson, K., Schenck-Fontaine, A., Hess, S., Leisher, C., Mutunga, C.,\& Honzak, C. (2018). Family planning and resilience: associations found in a Population, Health, and Environment (PHE) proyect in Western Tanzania. Population and Environment, 40, 204-238.

Herman, H., Stewwart, D.E., Diaz-Granados, N., Berger, E.L., Jackson, B., \& Yuen, T. (2011). What is resilience?.Can J Psychiatry, 56,pp. 258-265.

Hernández López, F., Hernández-Vázquez, M., \& Sánchez-Castillo M. (2013). "La salud sexual y reproductiva de las mujeres hablantes de lengua indígena, 1997-2009". In La situación demográfica de México 2013. CONAPO. Retrieved from http://www.conapo.gob.mx/ work/ models/CONAPO/Resource/2468/2/images/SDM_2013.pdf

Instituto Nacional de Estadística y Geografía INEGI. (2016). "Estadísticas a propósito del día Internacional de la Juventud (15 a 29 años) 12 de agosto". INEGI. Retrieved from http://www.inegi.org.mx/ saladeprensa/aproposito/2016/juventud2016_0.pdf

Instituto Nacional de Estadística y Geografía INEGI. (2015)Encuesta Nacional de la Dinámica Demográfica 2014. México: INEGI; 2015.

Instituto Mexicano de las Mujeres INM(n.a.) Breve análisis de la situación de salud reproductiva de mujeres de habla indígena y no indígenaResultados de la Encuesta Nacional sobre la dinámica demográfica 2006 y 2009. INM. Retrieved from http:// cedoc.inmujeres.gob.mx/ documentos_download/101214.pdf

Instituto Nacional de Salud Pública and Fondo de las Naciones Unidas para la Infancia INSP \& UNICEF. (2016). "Encuesta Nacional de Niños, Niñas y Mujeres 2015 - Encuesta de Indicadores Múltiples por Conglomerados 2015, Informe Final" INSP and UNICEF. Retrieved from https://www.unicef.org/mexico/ media/ 1001/ file/ UNICEF_ENIM2015.pdf

Karver, T. S., Sorhaindo, A., Wilson, K. S., \& Contreras, X. (2016). Exploring intergenerational changes in perceptions of gender roles and sexuality among indigenous women in Oaxaca. Culture, health $\mathcal{E}$ sexuality, 18(8), 845-859.

Jiménez, A., Granados, J.A., \& Rosales, R.A. (2017). Embarazo en adolescentes de una comunidad rural de alta marginalidad. Un estudio mixto de caso. Salud Pública de México, 59(1), 11-18. 
Organización Mundial de la Salud OMS. (2003). "Salud Reproductiva. Proyecto de estrategia para acelerar el avance hacia el logro de los objetivos y metas internacionales de desarrollo". OMS. Retrieved from http://apps.who.int/gb/archive/pdf_files/EB113/seb11315a1.pdf

Organización Mundial de la Salud OMS. (2016). "Recomendaciones de la OMS sobre atención prenatal para una experiencia positiva del embarazo". OMS. Retrieved from http://apps.who.int/ iris/ bitstream/ 10665/ 250802/1/WHO-RHR-16.12-spa.pdf

Organización Mundial de la Salud OMS. (2017a). "Salud Reproductiva". OMS. Retrieved from http:// www.who.int/ topics/ reproductive _ health/es/

Organización Mundial de la Salud OMS. (2017b). "Planificación familiar". OMS. Retrieved from http:// www.who.int/ mediacentre/ factsheets/ fs351/es/

Organización Mundial de la Salud OMS. (2017c). "Salud de la Madre, el recién nacido, del niño y del adolescente". OMS. Retrieved from http://www.who.int/maternal_child_adolescent/topics/maternal/r eproductive_health/es/

Organización de las Naciones Unidas ONU. (2017a). "La planificación familiar empodera a las mujeres y contribuye al desarrollo". ONU. Retrieved from http:// www.un.org/ sustainabledevelopment/ es/ 2017/ 07/ la-planificacion-familiar-empodera-a-las-mujeres-ycontribuye-al-desarrollo/

Organización de las Naciones Unidas ONU. (2017b). “Objetivo 5. Lograr igualdad entre los géneros y empoderar a todas las mujeres y las niñas". ONU. Retrieved from http:// www.un.org/ sustainabledevelopment/es/gender-equality/

Fondo de Población de las Nacionas Unidas UNFPA. (2010). “Salud sexual y reproductiva en poblaciones indígenas y afrodescendientes". UNFPA México. Retrieved from http:// www.unfpa.org.mx/ ssr_ indigenas.php

UNLa. Fundación Bernard Van Leer (2014). Resiliencia: tendencias y perspectivas. Buenos Aires, Argentina: EDUNLA.

Pinto, C. (2014). Resiliencia psicológica: Una aproximación hacia su conceptualización, enfoques teóricos y relación con el abuso sexual infantile. SUMMA psicológica UST, 11(2), 19-33.

Sanjuan-Meza, X.S., Landeros-Olvera, E.A., \& Cossío-Torres, P.E. (2018). Validez de una escala de resiliencia (RESI-M) en mujeres indígenas de México. Cadernos de Saúde Pública, 34(10), pp. 1-12. doi: 10.1590/0102311X00179717

Sarubin, N., Wolf, M., Giegling, I., Hilbert, S., Naumann, F., Gutt, D.,\& Padberg, F. (2015). Neuroticism and extraversion as mediators 
between positive/negative life events and resilience. Personality and Individual Differences, 82, 193-198.

Tomás, J. M., Sancho, P., Melendez, J.C., \& Mayordomo, T. (2012). Resilience and coping as predictors of general well-being in the elderly: A structural equation modeling approach. Aging and Mental Health, 16(3), 317-326.

Vargas Ruiz, R. (2007). Conocimientos, actitudes y prácticas en salud sexual y salud reproductiva: Propuesta de una escala psicométrica. ABRA. Revista de la Facultad de Ciencias Sociales Universidad Nacional, 27(36), 135- 167.

World Health Organization (WHO). (2009). Mental Health aspects of women's reproductive health: a global review of the literature. WHO. https://apps.who.int/iris/bitstream/handle/10665/43846/97892415 63567_eng.pdf;jsessionid=D92E28F457D11A89960EF30561579104?seq uence $=1$ 